\title{
Civilisations
}

Revue internationale d'anthropologie et de sciences

humaines

43-2 | 1996

Problèmes africains contemporains

\section{Malnutrition in the history of tropical Africa}

\section{Sjoerd Rijpma}

URL: http://journals.openedition.org/civilisations/1565

DOI: 10.4000/civilisations. 1565

ISSN: 2032-0442

\section{Publisher}

Institut de sociologie de l'Université Libre de Bruxelles

\section{Printed version}

Date of publication: 1 April 1996

Number of pages: $45-63$

ISBN: 2-87263-160-7

ISSN: 0009-8140

\section{Electronic reference}

Sjoerd Rijpma, «Malnutrition in the history of tropical Africa », Civilisations [Online], 43-2 | 1996, Online since 29 June 2009, connection on 19 April 2019. URL : http://journals.openedition.org/ civilisations/1565; DOI : 10.4000/civilisations.1565

\section{(C) Tous droits réservés}




\title{
Malnutrition in the history of tropical Africa.
}

\author{
Dr Sjoerd RIJPMA \\ Wageningen University
}

\section{Résumé}

La malnutrition est devenue structurelle au vingtième siècle chez les enfants d'Afrique tropicale. Elle n'apparait cependant que comme un phénomène fortuit dans les statistiques médicales sur l'Afrique du dix-neuvième siècle.

Les causes de cette alimentation insuffisante et des naissances plus rapprochées se trouvent dans les boulversements des conditions politiques et écologiques ainsi que des relations socio-culturelles et socio-économiques, qui, dans tout le continent, ont engendré des répercutions dès le début de la deuxième moitié du dix-neuvième siècle.

Avant 1880, des voyageurs formés en médecine ont montré, avec des preuves concrètes et circonstanciées, que la plupart des populations d'Afrique tropicale n'étaient pas encore structurellement perturbées.

Malnutrition, a condition with specific symptoms, is the foremost cause of death among African children. The first description as a clinical entity dates from $1932^{1}$.

* I am very grateful to Mrs B.C.C. van Stolk-Tyacke for her adaptation of the text.

1. WILLIAMS, CECILY D. Deficiency diseases in infants. Gold Coast Colony annual medical report, 1931/1932, 93-95 

existed?

A crucial question not posed before is: has it always

I want to distinguish between primary and secondary malnutrition. Primary malnutrition existed during the adaptation of man to his surroundings, before women had appreciated the preventive effects of protracted lactation, and of appropriate weaning foods, and before the community was forced to establish rules for sexual intercourse to prevent pregnancy during lactation. Primary malnutrition returned when, as a result of changing habitat or/and techniques, new weaning foods had to be found.

The subject of this paper is secondary malnutrition, which occurs when and where the (opportunity to apply the) above knowledge has been lost. This presupposes structural societal disturbances, which have to be considered together with the factors deciding the ultimate magnitude of the problem.

The following exposé will make clear why modern classifications of malnutrition will not be used by me, being irrelevant to this study. (see also ref.3.)

\section{An old plague finally discovered?}

In the 1930s Cecily Williams described a condition, found among African children between six months and four years of age $^{2}$, characterized by irritability, diarrhoea, swelling of hands and feet, and changes of skin and hair ${ }^{34}$. She first published it

2. TROWELL, HUGH. The beginning of the kwashiorkor story. Afya, May/June 1975,66

3 WILLIAMS, CECILY D. A nutritional disease of childhood associated with a maize diet. Archives of disease in childhood, 1933, 423-433. For this publication I prefer Williams' diagnostic characteristics above the modern definition of 'malnutrition', as the precolonial medical observers were not able to use the modern means to make the diagnosis certain.

4. Later also: enlargement of the abdomen. 
under the heading "deficiency diseases", then "nutritional disease", kwashiorkor". and "malnutrition"6, a lethal condition unless treated very early?. Its cause was an abnormal diet: breastfeeding by a pregnant mother or an old woman, and insufficient weaning food: maize. The period of breast-feeding had been much shorter than normal ${ }^{8}$. She considered African women ignorant in nutrition matters ${ }^{9}$, though they knew what kwashiorkor meant ${ }^{1011}$. The treatment was dietetic: cod-liver oil,

5 WILLIAMS, CECILY D. Kwashiorkor. A nutritional disease of children associated with a maize diet. Lancet, 1935, 1151-2: her translation of this Ga word was: "the disease the deposed baby gets when the next one is born", in 1963 she wrote in The Courrier: "The etymology of the word is not quite certain." (p.361); FIELD, M.J. Religion and medicine of the Gâ people. (orig. 1937), reprint New York, 1979, 165 (kwa ioko).

6. WILLIAMS, CECILY D. Child health in the Gold Coast. Lancet, 1938, 98. DAVIDSON, S.; R. PASSMORE, M.A. EASTWOOD. Human nutrition and dietetics. London: Churchill Livingstone, 1986. See there for the present definitions of Malnutrition.

7. WILLIAMS, CECILY D. (1931/1932), 93.

8. WILLIAMS, CECILY D. (1933), passim, 423-433.

9 WILLIAMS, CECILY D. (1933), passim, 482; still in 1979 "Ignorance [and poverty] are the two main causes". in DAVIDSON S., R. PASSMORE, J.F. BROCK, A.S. TRUSWELL. Human nutrition and dietetics. 7th ed. Edinburgh, London, New York: Churchill Livingstone, 1979, 266.

Later Kimati and others questioned her opinion (KIMATI, VALERIAN P. "Who is ignorant? Rural mothers who feed their well-nourished children or the nutrition experts. The Tanzania story." Journal of tropical paediatrics, 32, 1986, 130-136; HOORWEG, J, R. NIEMEIJER. The effects of nutrition rehabilitation at three family life training centres in Central Province, Kenya. Leiden: African Studies Centre, 1982.

10. Also in East Africa an explanatory word was used: chirwa. GERLACH, L.P. Some basic Digo conceptions of health and disease. In: Attitudes to health and disease among some East African tribes. One day symposium. December, 1959. East Africa Institute of social research, Makerere College, Kampala, Uganda, 12: chirwa means "to pass a bad path, and thus to break a taboo". in A standard Swahili-English dictionary, founded on Madan's Swahili-English dictionary. By the interterritorial language committee of the East African Dependencies under the direction of the late FREDERICK JOHNSON. London: Oxford University Press, Geoffrey Cumberlege, 1st ed. 1939, reprint 1951, 57: the harm done is called chira: "for instance, if they [the parents] have intercourse within the prohibited period after the birth of the child".

11. TROWELL, H.C., DAVIES J.N.P. and DEAN R.F.A.. Kwashiorkor, London: Edward Arnolds, 1954, 283 found another thirty-two native names for 
malt, tinned milk. Once at home, many children who had recovered in hospital died of the original condition ${ }^{12}$.

In tropical Africa other doctors had described the symptoms before she did ${ }^{13}$, but Cecily Williams combined them into a clinical entity, based upon aetiological factors.

In 1935 she counted some sixty cases in three years ${ }^{14}$, five years later "probably less than 50 per cent. of the babies born alive survive[d] to maturity"15. In 1952, unknown to the textbooks, "kwashiorkor [was] the most serious and widespread nutritional disorder"16, in 1979 "it [was] largely responsible for the fact that in many areas up to half of the children born do not survive to the age of 5 years"17. In 1985 Unicef was "faced with the malnutrition and ill health which claim the lives of nearly four million African children each and every year" ${ }^{\prime 18}$. This is not the temporary problem of primary malnutrition, but a structural catastrophe.

kwashiorkor in Africa. I can add: Iwinzi, alisata lusi (Kinyamwezi: a swollen stomach of a child whose mother had become pregnant before having weaned this child); ekima (Lukonjo)(meaning unknown); obwasi (Ganda: lack of mother's care because of a new baby); eryose (Rutoro): same meaning. Analysis of these words lies in the future efforts of linguists and physicians.

12. Which experience I have shared in my time as a doctor in a part of tropical Africa where cassava was the weaning food.

13 WILLIAMS, CECILY D. (1935), passim, n.31 (R.U. Gillan), n.32 (Dyce Sharp), TROWELL, H.C. et al. (1954), passim, 2-4, 291, 293, 295.

14. WILLIAMS, CECILY D. (1935), passim, 1151.

15. WILLIAMS, CECILY D. (1938), passim, 97.

16. BROCK, J.F., AUTRET M.. Kwashiorkor in Africa. Geneva: WHO,1952, xxi.

17. DAVIDSON S., R. PASSMORE, J.F. BROCK, A.S. Truswell. Human nutrition and dietetics, 7th ed. Edinburgh/London/New York: Churchill Livingstone, 1979, passim, 255.

18. Within human reach. A future for Africa's children. New York: UNICEF, 1985, i. 


\section{A white raven in precolonial Africa?}

How structural must disturbances be to cause secondary malnutrition? Can its symptoms be found in European medical publications about tropical Africa before $1880^{19}$ ?

In the course of research for a book on the precolonial history of health and nutrition in tropical Africa, I made an analysis of 91 printed works of 63 European doctors and of one African doctor trained in European medicine ${ }^{20}$, because particularly doctors were able to interpret in black children basic symptoms like hair and skin changes, diarrhoea, oedema, large abdomens: during the Industrial Revolution (since about 1760) an analogous deficiency disease, "Mehlnährschaden"21, existed among white children in Europe. Falkenstein observed African children in the Loango-area with protruding abdomens, "just as white children, who had consumed large quantities of carbohydrate-rich food in early youth". But in black children the cause was a "too prominent lordosis"22 and not deficiency:

19. This year is arbitrarily chosen as the beginning of the colonization: in 1879 the French and German advance in West Africa began; the British started some years earlier. (FAGE, J.D. A history of West Africa. Cambridge: at the University Press, 1969, 165.) PHILIP D. CURTIN uses the same year in: Precolonial African History. The American Historical Association, 1974, 23, as did A. ADU BOAHEN in: African perspectives on colonialism. Baltimore: John Hopkins University Press, 1987, 29.

20. The only African is J.A.B. HORTON. The printed works include later edited collections of journals and/or letters. 9 doctors gave insufficient information on the subject and another 7 gave no information at all. Only 75 publications by 57 doctors were of use.

21. CZERNY, A., KELLER A.. Des Kindesernährung, Ernährungsstörungen und Ernährungstherapie. Wien: F.Deuticke, 1906.

22. FALKENSTEIN, J. Die Loango-expedition, ausgesandt von der Deutsche Gesellschaft zur Erforschung Aequatorial-Afrikas 1873-1876, ein Reisewerk in drei Abtheilungen von P. Güssfeldt, J. Falkenstein, Ed. Pechel-Loesche. Teil I. zweite Abtheilung. Leipzig: Paul Frohberg, 1879, 29.

* : European physician or surgeon who travelled in tropical Africa before 1880, and whose printed document (book, article) is of value for the research of the subject "Health and nutrition in historical tropical Africa". 
"infants and children [were] to be envied for their health; mortality among them [was] relatively low, contrary to the situation in Germany, where infant and child mortality was frightfully high". In many areas the average negress gave birth to two or three children, a "victorious self-help of nature, to prevent overpopulation". In Sierra Leone three to four was the rule, and among the Mandingoes five to six, less than in nineteenth century Europe $^{23}$. Low fertility originated also in polygamy ${ }^{24}$. In the second half of the nineteenth century fertility was high in Bornu, Chad and Uganda, areas of unrest, as was Senna (Mozambique), where "the breeding of children [was] a difficult process. They often die"

Low birth figures were not attained "artificially by criminal means ${ }^{126}$. Falkenstein acknowledged birth-control, and

** : editor of letters or works of a European physician or surgeon who travelled in tropical Africa before 1880.

23 DANIELL, W.F. Sketches of the medical topography and native diseases of the Gulf of Guinea, Western Africa. London: S. Highley, 1849, 97.

**STUHLMAN, F. (ed). Die Tagebücher von *Dr. Emin Pascha. Band 11875 1878. Hamburg: Georg Westermann, 1916, 300. $($ Emin Pascha $=$ Dr. Eduard Schnitzer).

*WINTERBOTTOM, T.M. An account of the native Africans in the neighbourhood of Sierra Leone, to which is added an account of the present state of medicine amongst them. 2 vols. (orig. 1803) 2nd ed. London: Frank Cass, 1969, 150.

*PARK, M. Travels in the interior districts of Africa, in the years 1795, 1796, 1797. London: W. Bulmer, 1799, 265.

24.*DANIELL, W.F. (1849), passim, 99. WINTERBOTTOM, T.M. (1969), passim, 148.

STUHLMANN, F. (1916), passim, 461.

**WALLER, HORACE.(ed.) The last journals of David *Livingstone in Central Africa, from 1865 to his death.[-] 2 vols. London: John Murray. 1874, 51.

*LIVINGSTONE, D., LIVINGSTONE C.. Narrative of an expedition to the Zambesi and its tributaries and of the discovery of the lakes Shirwa and Nyassa 1858-1864. London: John Murray, 1865, 284.

25. NACHTIGAL, G. Sahara und Sudan. Herausgegeben von E.Groddeck. BerlinLeipzig: Weidmannsche Buchhandlung/ Wiegandt, Hempel \& Parey, 1879-1889, II. 465 .

**FOSKETT, R. The Zambesi journal and letters of Dr. John *Kirk 1858-1863. 2 vols. Edinburgh \& London: Oliver \& Boyd, 1965, 159.

26. FALKENSTEIN, F. (1879), passim, 40-41. 
mentioned the taboo on sexual intercourse for women during pregnancy and lactation ${ }^{27}$. Lactation periods lasted from two to four years. "Should intercourse take place, it would either destruct the infant now or later"28. As to "criminal methods", a child who cut its upper teeth before the lower one, was sometimes killed or sold $^{29}$; abortion and infanticide were mentioned $^{36}$. In 1849 Livingstone observed in the Kalahari desert fugitives of "a timid race (-) with thin legs and arms, and large protruding abdomens caused by the coarse indigestible food they eat" ${ }^{131}$. In Sierra Leone, where "[children's] diseases are very few" ${ }^{132}$, Winterbottom saw sometimes swellings of the lower extremities, which proved fatal if not treated with emetics and

27. se also *DALZEL. A. The history of Dahomey, an inland kingdom of Africa. (orig. 1793) London: Frank Cass reprint, 1967, xix. DANIELL, W.F. (1849), passim, 55.

*ISERT [P.E.] Reize van Koppenhagen naar Guinea. Naar het Hoogduitsch. Amsteldam: vd Burgh, Craijenschot, Holtrop, vd Kroe, van Hulst en van Es, 1797, 211, WALLER, HORACE (1874), passim, 51., NACHTIGAL, G. (18791889), passim, 465., LAIRD, MAC GREGOR, R.A.K. *Oldfield. Narrative of an expedition into the interior of Africa by the river Niger, in the steam-vessels Quorra and Alburkah in 1832, 1833, and 1834, 2 vols. (orig. 1837). London: Frank Cass, new impression, 1971, 97. PARK, M. (1799), passim, 265, STUHLMANN, F. (1916), passim, 314. WINTERBOTTOM, T.M. (1969), passim, 193-227.

28. DANIELL, W.F. (1849), passim, 55 (also D.Livingstone (1857))

29. ** SCHAPERA, I. (ed.). *Livingstone's private journals 185I-1853. London: Chat to and Windus, 1960, 159.

** SCHAPERA, I. (ed.). *Livingston's African journal 1853-1856, 2 vols. London: Chatto and Windus, 1963, II, 404. WALLER, HORACE (1874), passim, 189. 276. ALLEN W., *THOMPSON T.R.H.. A narrative of the expedition sent by Her Majesty's Government to the Niger in 184I under the command of Captain H.D. Trotter, R.N., in two volumes, (orig. 1848). London: Frank Cass, new impression, 1968, 243.

30. WINTERBOTTOM, T.M. (1969), passim, 215.

*HUTCHINSON, 'T.J. Impressions of Western Africa with remarks on the diseases of the climate. London: Frank Cass, new impression, 1970 (orig. 1858), 165.

See also: WILKINSON, R.G. Poverty and progress. London: Methuen \& Co. Ltd, $1973,39-40$.

31. *LIVINGSTONE, D. Missionary travels and researches in South Africa; (-). London: John Murray, 1857, p.50.

32. WINTERBOTTOM, T.M. (1969), passim, 219. 
purgatives ${ }^{33}$. He mentioned "dirt eating" among children, which led to changes in skin colour and texture; the abdomen became enlarged, the lower extremities anasarcous ${ }^{34}$. In one family in Freetown he observed "woolly hair of a dirty red or singed colour" ${ }^{35}$. Many children had "prodigiously large bellies", without being ill ${ }^{36}$.

Galton observed Damara-children with large bellies and emaciated figures ${ }^{37}$. In war-time Sudan some children had large abdomens, caused by "sometimes too much food and then, too little ${ }^{138}$.

Altogether in the nineteenth century only a few African children have been observed with one to three symptoms, by 5 of the 64 doctors. Even if this were evidence of the existence of malnutrition, the incidence was low. The presence of aggravating circumstances (disturbances by foreign influences and/or war) points to secondary malnutrition, but of low magnitude.

Not to overlook the occurrence of malnutrition in the texts, "circumstantial evidence" was sought: observations of deficiency-diseases, reports of excessive child morbidity or mortality, lack of food, underdeveloped agriculture.

33. WINTERBOTTOM, T.M. (1969), passim, 222.

34. JOHN FORD mentioned dirt eating as a symptom of sleeping sickness: Ford, John. The role of the Trypanosomiases in African ecology. Oxford: Clarendon Press, 1971, 247. Livingstone mentioned Safura=clay or dirt eating among adults in his last journals: Waller, Horace (1874), passim, II, 83-84.

35. WINTERBOTTOM, T.M. (1969), passim, 193. Winterbottom referred to Pigafetta, who had said that the (adult) Congo negroes had black curly, and frequently red hair; in: PIGAFETTA, FILIPPO. A report of the Kingdom of Congo, and of the surrounding countries, drawn out of the writings and discourses of the Portuguese, Duarte Lopez, by Filippo Pigafetta, in Rome, 1591. (Newly Translated by Margarite Hutchinson, London, 1881. New impression, London, 1970.)

36. WINTERBOTTOM, T.M. (1969), passim, 227.

37. ${ }^{*}$ GALTON, F. The narrative of an explorer in tropical South Africa. (orig. 1853). New York-London: Johnson reprint corporation, 1971, 192.

38. STUHLMANN, F. (1916), passim, 1, 314: "Bald zuviel, bald Hunger". 
First, eighteen publications by 16 doctors, who visited tropical Africa before the nineteenth century $(8 \text { before } 1760)^{39}$, have been analysed. They mentioned several diseases, like "dysentery", fevers during the rainy season (mostly malaria, treated with "the bark", "Kina"), ulcers, worm diseases ${ }^{40}$, leprosy, jaundice, anal fistula, which were cauterized, venereal diseases, scabies, convulsions and once apoplexy. Bruce saw two famished girls in war-time Ethiopia. The Mandingoes, generally healthy, did not live to more than sixty ${ }^{41}$. Smallpox was rare, as the Africans inoculated in many areas, and enforced quarantine. Several native medical and surgical interventions were mentioned $\mathrm{d}^{42}$. Most doctors commented on an abundance of food: rice, millet and sorghum, yams, sweet potatoes, maize, plantains, bananas and many more cultivated and wild fruits, various vegetables, sugar cane, palm tree products, honey, milk, wild and cultivated roots as cassava, meat of domestic and wild animals. Others registered the sparse use of meat, but an abundance of fish.

"They produce all the necessaries of life", and "they never starve" are repeated statements. Poverty was met by Bruce; Park described seasonal hunger: "before they gathered in their present crops, they had been for 29 days without tasting corn"43. Mainly

39. not included are the books about Africa by famous medical authors like Dapper, Leyden and Ludolph. Like many well-known Arab doctors they never visited tropical Africa themselves. Also excluded are works by Lind and Schotte, and one publication by Atkins, resp. Houston, not covering the present subject.

40 Pulex penetrans and Taenia, by Bruce recognized as the result of eating raw meat: in: *BRUCE, J. Travels to discover the sources of the Nile, in the years $1768,1769,1770,1771,1772$ and 1773 , in five volumes. London: G.G.J. \& J. Robinson, 1790.

41. PARK, M. (1799), passim, 274.

42. e.g. "insufflation", see: *GALLANDAT, D.H. Aanmerkingen over de genezinge van eenige langduurige kwaalen, door eene onbekende heelkundige operatie, by sommige Guineesche Negers in gebruik. Verhand. Holl. Maatsch. $v$. Wetensch., 1761: V1: 2: 676-687.

43. PARK, M. (1799), passim, 336: they consumed the pods of the mimosa and bamboo seeds (a modern source for the same area in Senegambia now mentions a period of more than 4 months)(verbal communication by Prof. Dr. J.P.M. VAN DEN BREEMER). 
women cultivated the fields, producing an amazing abundance and variety of food with up to three harvests per season; men procured meat and fish. Agricultural areas were "well cultivated and well peopled"; the visitors saw "the finest herds of cattle".

The number of printed documents written by doctors in the nineteenth century mirrors the increased interest of Europe in tropical Africa: in the first fifty years there were twenty-five publications ( 23 doctors) and from 1851 to 1880 forty-four ${ }^{44}$ (25 doctors $)^{45}$.

Winterbottom, who spent seven years in Sierra Leone, Daniell, Johnston, Tedlie, and Smith agreed upon the good health of the inland populations and the poorer health of the natives on the coast ${ }^{46}$. To the diseases among Africans they added: colics of the bowel, rheumatism, cataract, "ophthalmia" and insect bites; imported diseases in coastal areas (elephantiasis Arabum, pneumonia, pleurisy, tuberculosis, venereal diseases, hepatitis from alcohol abuse) $)^{47}$. Infant and child mortality in the maritime regions and in Ethiopia was high. The doctors of the Niger expedition stated that the further they ascended the river, the healthier the natives were. Native doctors' diets and treatments were appreciated, but not their "magic". Their fracture treatment was "successful in every instance"

44. included twelve collections of journals and/or letters, written by a doctor and published by an editor (marked $* *$ in the references and in the bibliography).

45. Most were in government service and the majority penetrated into the interior, driven by "thirst for discovery, a spirit of commercial enterprise, and to suppress the slave trade". (Allen W., T.R.H. Thompson. (1968), passim, 22ff).

46. WINTERBOTTOM, T.M. "Account of the present state of medicine among the natives of Sierra Leone" (1803) (in which one finds the first reliable description of sleeping sickness): this is vol. II of: Winterbottom, T.M. (1969), passim.

47. Many diseases which are now considered to be "tropical" were then, or had been, present in Europe: cholera, malaria, typhoid, etc. The doctors of that time were trained to diagnose these diseases. Their textbooks, e.g. by Leyden, are quite reliable.

48. WINTERBOTTOM, T.M., (1969), passim, 203. 
Nutrition was very good in the interior, but famines succeeded the Fante invasions in Ashantee $^{49}$, and the war in Ethiopia. The Bornu expedition found only millet and meat in abundance, whereas previously there had been a wide variety of food $^{50}$. Extensive lists of food items were published by several doctors ${ }^{51}$. The cultivators "with their hoes of iron (-) merely scratching the surface (-), succeeded in raising good crops", but never more than they could use ${ }^{52}$. Women worked very hard; "their progress in agriculture is not inferior to that of the most enlightened countries of Europe" ${ }^{153}$. Agriculture, cattle raising, fishing, hunting, gathering procured a wide variety of food, though consumption of meat was sometimes limited.

During the next thirty years slave raids in Central Africa continued. However, the slave-trade was concentrated on the east. But now European intervention (Sudan, South Africa, Ethiopia) and exploration of the interior had begun. For this period Livingstone is the most comprehensive source, followed by Schnitzer (Emin Pascha), Junker, Felkin, Holub, Nachtigal, Falkenstein, Galton, and Kersten. Some, like Christie, Meller, Corre, paid attention to one disease: respectively cholera, malaria,

49. *TEDLIE, H. Materia medica and diseases, in: Bowdich, T.E. Mission from Cape Coast Castle to Ashantee. 3d ed. London: Frank Cass, 1966 (1st ed. 1819), $182 \mathrm{ff}$.

50.**BOVILL, E.W. Missions to the Niger, vol. II \& III: The Bornu mission 1822-25: Narrative of travels and discoveries in Northern and Central Africa in the years 1822, 1823, and 1824 by Major Denham, Captain Clapperton and the late Doctor *Oudney. Nendeln Liechtenstein: Kraus reprint, 1975 (orig. London: Cambridge University Press, 1826), 515.

51. *BOYLE, J.A. A practical medico-historical account of the Western coast of Africa. London: S. Highley, 1831, 36-37, WINTERBOTTOM, T.M. (1969), passim, 46-63.

52.. Narrative of an expedition to explore the river Zaire, usually called the Congo, in South Africa, in 1816, under the direction of Captain J.K.Tuckey, R.N., to which is added the journal of Professor *Smith; some general observations on the country and its inhabitants; and an appendix [Mr TUDOR MD, comparative anatomist]. London: J. Murray, 1818, 363. It was not yet known that in many places the fertile layer was but a few inches thick.

53. *HELLIS, C-E. Les bords du Niger. Rouen: Bourquelot, 1833, 15. 
and sleeping sickness ${ }^{54}$. endemic diseases become epidemic. The travellers added: swollen thyroids, filariasis, yaws, bloody urine (Schistosomiasis?), "an insect in the aqueous chamber of the eye ${ }^{155}$, relapsing fever ${ }^{56}$, typhus and prolapsus ani, mostly isolated cases. They rarely saw yellow fever, or malformations. The Africans seldom died of malaria, except as migrants from non-malarious areas ${ }^{57}$. Kirk diagnosed a case of "hepatia abscess", but "the natives make a better job [of it] than I can"s8.

Wars brought new diseases ${ }^{59}$, particularly among fugitives and slaves, and spread old ones ${ }^{60}$, while caravans carried epidemics ${ }^{61}$. Generally the African children were healthy, except in areas under European control.

Several treatments were described, and tried out ${ }^{62}$, like herbs, medicinal springs, "Kina bark". A score of nutrients were observed. When cultivated food was scarce, the Africans lived on food-gatherings ${ }^{63}$. In Ethiopia king Theodoros devastated many very fertile areas and on the Angolan and Mozambican coast "miserable people" were seen. Kirk and Livingstone met starving people wherever slavers were active, as did Schnitzer in Sudan.

54. as did: DANGAIX (1861), NICHOLAS (1861), GAIGNERON LA GUILLOTINIËRE (1864), CHASSIANOL (1865), SANTELLI (1868), GUÉRIN (1869) and LE ROY DE MÉRICOURT (1871), whose publications have been left out as being too limited.

55. WALLER, HORACE (1874), 233 (onchocerciasis?)

56. the only disease discovered by D.LIVINGSTONE.

57. SCHAPERA, I. (1963), II, 311.

58. FOSKETT, R. (1965), I 222.

59 LIVINGSTONE, D. (1857), passim, 185-186.

60. M'BOKOLO, E. Histoire des maladies, histoire et maladie: l'Afrique. In: Le sens du mal, sous la direction de MARC AUGÉ ET CLAUDINE HERZLICH. Paris: Editions des Archives Contemporaines, 1984, 174.

6I. WALLER, HORACE (1874), passim, II, 96, *CHRISTIE, JOHN. Cholera epidemics in East Africa. London: MacMillan \& Co, 1876.

62. LIVINGSTONE, D. (1857), passim, 188.

$63{ }^{*}$ HOLUB, EMIL. Seven years in South Africa, travels, researches and hunting adventures between the diamond fields and the Zambesi (1872-1879), translated by E. Frewer, 2 vols., London: Sampson Low, Marston \& Co's, 1881 (orig.); reprint Johannesburg: Africana Book Society, 1975, 111. 
Positive estimates of native food production systems are the rule. Hartmann wrote a scientific survey ${ }^{64}$, while others gave information on specific regions: "Immense fields of durra" (Uganda), and plenty of game, a "paradise with herds of cattle" (Benguela and Kanem), "intelligent careful agriculturists in a land of great plenty" (South-west Africa), "overplus for hunters and traders" (Barotse valley), "great, industrious, hard working agriculturists" (West coast), "not a single inch of ground is uncultivated, to an immense extent" along the Niger and in Uganda; "very beautiful cattle" along the Zambesi, in pastures where "one believes oneself to be in Holland": these are but a few of the many superlatives used. Others, like Galton, and Livingstone, described specialization in agriculture, when population-increase had made this necessary ${ }^{65}$, with animal or vegetal manure (lupine ${ }^{66}$ ), by irrigation, intercropping, planting on ant-hills, transfer of crops from nurseries to definite fields.

But Griffon du Bellay registered deforestation in Gabon by French companies.

Women were the main agriculturists in many areas, had a leading role in markets, and worked very hard in their households; men cleared the grounds, did the planting, practised various industries, though in some areas they were "not very laborious", and were "only" hunters, fishermen or cattle-holders.

\section{Malnutrition before the colonization of Africa.}

The doctors' "circumstantial evidence" within my material is by comparison with other travellers (e.g. Bosman, Barth) reliable. However, even if they travelled in Africa for several years, they seldom stayed in one place for long. But, they knew

64.*HARTMANN, R. Die Nigritier. erster Theil. Berlin: Wiegandt, Hempel \& Parey, 1876, 115-141.

65 e.g. LIVINGSTONE, D, C. LIVINGSTONE.(1865), passim, 498-499.

66. already described by J.BRUCE (1790), passim, 299. 
about food production, then still Europe's first industry. And: doctors had been trained in the knowledge of food and dietetics, perhaps their most important treatment. Illness of children was a common occurrence in Europe. Diagnostic skills had periodbound limitations: e.g. physicians before 1760 may lack knowledge of Mehlnährschaden.

Till the end of the nineteenth century birth-spacing was usual in tropical Africa. The first two stages of Notestein's demographic transition $^{67}$ having been passed, there were relatively few births, and low mortality ${ }^{68}$. Notable exceptions have been mentioned above (page 2). Most populations had found adaptations to socio-economic disturbance and were described as forming part of the ecology ${ }^{69}$, even though the slave trade had disturbed their communities, and diminished the population ${ }^{70}$. Apparently Africans were more resilient than Rodney $^{71}$ and Darkoh ${ }^{72}$ assumed ${ }^{73}$. Many migrations of peoples were gradual and did not lead to structural disorganization ${ }^{74}$. Wars were mostly local and temporary ${ }^{75}$, except the ones started

67. KING, M. Health is a sustainable state. Lancet, 1990, 664: this model of demographic transition depends on experiences from the industrial world.

68. Adoption of the Omaha system of kinship terminology, where the Crow system had been in use, may even have a medical explanation: when maternal mortality decreased, women became a more stable asset.

69. see also: WILKINSON, RICHARD G. (1973), passim, 8-58.

70. KUCZYNSKI, R.R. Demographic survey of the British colonial empire, 2 vols. London: Oxford University Press, 1949.

71. RODNEY, WALTER. How Europe underdeveloped Africa. London: BogleL'ouverture publications, 1983.

72. DARKOH, M.B.K. The underlying causes of the food crisis in Africa. Transafrican journal of history, 1989, 60 .

73. THORNTON, JOHN. Demography and history in the kingdom of Kongo, 1550-1750. Journal of African History, xviii, 4(1977), 507-530, THORNTON, JOHN. The slave trade in eighteenth century Angola: effects on demographic structures. Canadian Journal of African Studies, 14.3.1980, 417-427.

74. MILLER, JOSEPH C. The Imbangala and the chronology of early central African history. Journal of African History, xiii, 4, 1972, 554, OGOT, BETHWELL. The impact of the Nilotes. In: Oliver, R.(ed.) The middle age of African history. London, 1967, 47. 
by or on behalf of European, Arab or African slave dealers. Wars and droughts led to hunger, but even then natives did not lose their customs and the knowledge of how and where to procure food ${ }^{76}$. Normally African adults and children were healthy. Livingstone mentioned many diseases that were not found among them.

Some symptoms of malnutrition, abnormal mortality among children, and starvation have been observed in regions where foreign influences had caused disturbances. Secondary malnutrition was (still) incidental, the areas of structural disturbances were limited.

\section{The spread of secondary malnutrition.}

The fact that the incidence of malnutrition increased during the twentieth century, leads to the question: why did the two determinating factors, considerable shortening of the lactation period and early weaning with inferior products, become general? This can only be explained by the influences of the "pacification" which Livingstone and others found necessary ${ }^{77}$. The result of the European conquest of Africa between 1880 and 1920 was an enormous loss of population by war, hunger and disease $^{78}$, incomparably greater than during the 300 years of

75. BURTON, R.F. The Lake regions of Central Africa. 2 vols. London: Longmans, 1860, II. 331.

WALLER, HORACE (1874), passim, I, 39.

76. FOSKETT, R. (1965), passim, II, 498.

77. Others have gone into the impact of colonization see e.g. ADU BOAHEN, A. African perspectives on colonialism. Baltimore: John Hopkins University Press, 1987; General history of Africa, VII, Africa under colonial domination 18801935 (ed. A. ADU BOAHEN), Paris: Unesco, 1990; Cambridge History of Africa, volume 6 (1870-1905), edited by ROLAND OLIVER and G.N. SANDERSON. Cambridgc: Cambridge University Press, 1985; and idem volume 7, from 1905 to 1940, edited by A.D. Roberts. Cambridge: Cambridge University Press, 1986. VANSINA. JAN. Paths in the rainforests. London: James Currey, 1990, 239-248. 78. VANSINA concluded that 40 years of war destroyed the equatorial tradition, and broke African resistance "at the cost of an estimated half of the total 
slave trade. Endemic diseases like sleeping sickness ${ }^{79}$ and malaria ${ }^{80}$ became epidemic. Whole communities disappeared. The Africans now had to adjust to European law and religion, which they had succesfully resisted in the centuries before. They could not adapt their traditions under these circumstances, and stagnating traditions die out ${ }^{81}$. This also negatively influenced customs as prolonged lactation and sexual abstinence during pregnancy and breastfeeding. Though missionaries did everything to repress these customs, also other factors were important. Women had to work harder than ever. Forced labour and migrations led to loss of men in agriculture, which enlarged the women's workload. Protracted breast-feeding and the contraceptive effect of lactation disappeared ${ }^{82}$. Taxation forced the producers to grow cash crops, which resulted in a smaller area and less time for their own food ${ }^{83}$. Others had to leave their fertile areas, which were made into plantations or game reserves $^{84}$. Long existing, ecological systems of farming, husbandry, fishing, hunting and gathering ${ }^{85}$, became unbalanced when large numbers of men had gone ${ }^{86}$. New laws forbade the Africans to fish and to hunt in many areas ${ }^{87}$, while herds of cattle had to be reduced. They had lost all political control. The changes in food-production, as the adoption of crops that needed less

population of the area" and he went on to show that also in other regions the results may have been as disastrous (Vansina, Jan. (1990), passim, 239-245).

79. FORD, JOHN (1971), passim.

80. LIVINGSTONE, D. (1857), passim, 185-186.

81. VANSINA, JAN. (1990), passim, 260.

82. KONNER, MELVIN, WORTHMAN CAROL. Nursing frequency, gonadal function, and birth spacing among !Kung hunter-gatherers. Sci. nce, vol.207, 1980, 788-791.

83 Later "nutritional intervention", read: cash crop production for export, led to the crumbling of the "once diversified indigenous food systems of Africa". (LITTLE, MARION. Imperialism, colonialism and the new science of nutrition: the Tanganyika experience, 1925-1945. Soc.sci.med. (1991) vol.32,1,11.)

84. KJEKSHUS, H. Ecology control and economic development in East African history. London: Heinemann, 1977,

85. SCHOFFELEERS, J.M. (ed.). Guardians of the land. Essays on Central African territorial cults. Gwelo: Mambo press, 1978, 1-2, 41-43.

86. FORD, JOHN (1971), passim, 194.

87. KJEKSHUS, H. (1977) passim. 
labour, led to nutritional disbalances ${ }^{88}{ }^{89}$, and explain the insufficient spectrum of weaning foods. It was not the maize that caused malnutrition, as it was a staple food since the 17th century ${ }^{90}$ : a failing innovation would have been discontinued by the Africans themselves. But maize only was not enough.

In the second half of the twentieth century development aid brought new disturbances. "Ignorant" African farmers are instructed how and what to cultivate, with a focus on men, even in female farming systems, fertile subsistence-farming areas are still being alienated for cash crop production, helped by the change from indigenous to European legal systems ${ }^{91}$, industries are subsidized which attract labour from agricultural areas ${ }^{92}$.

And apart from all his, AIDS appeared, and it is still a guess what the result of this epidemic will be ${ }^{93}$.

88. WILLIAMS, CECILY D. The story of kwashiorkor. "Courrier" of the international children's centre. Vol.XIII, 6, 1963, 364, TAYLOR, R.Y. Ecology of kwashiorkor. British Medical Journal, 1962, 1762-3: Kwashiorkor as a manmade disease; Livingstone considered hunger to be a man-made disease (Waller, Horace (1874), I, 142).

89. "Custom (-) determines that the limited supply of foods of animal origin is given mainly to the men". (DAVIDSON S. ET. AL. (1979), 256: perhaps the writers mean, that in times of scarcity other priorities exist.

90. MAREES, PIETER DE. Description and historical account of the Gold Coast of Guinea (1602). Trad. and edit. by Albert van Dantzig and Adam Jones. London: 1987, 216: already in 1600 maize was an important staple on the Gold Coast and not much later everywhere in Africa.

91. KLUDZE, A.K.P. Property law and rural development in Ghana. Rural Africana, 17, 1983, 66-67, AGONDJO-OKAWA, P.L. Les droits fonciers coutumiers au Gabon. Rev. jur. et pol., 24, 1970, 4, 1135-11. 2.

92 BOSERUP. ESTHER. Woman's role in economic development. New York: St. Martin's Press, 1970, 196.

93. Kambou, Gerard. The economic impact of AIDS in an African country: simulations with a computable general equilibrium model of Cameroon. Journal of African economies, vol. I, nr.1, 1992, 109-130. 


\section{Will there be an end to malnutrition? Conclusion.}

My analysis suggests that between 1596 and $1880^{94}$ secondary malnutrition only existed in areas of tropical Africa under foreign influence. It exploded, however, since 1880 , and particularly in the twentieth century, because basic customs had been effectively destroyed during the period of colonization. During independence the disastrous effects continued: tradition had died out.

In 1989 more African children than ever "died by the slowing down or the reversal of progress in the developing world" 55 . Immunization and oral rehydration therapy had "saved children's lives"96, temporarily, as the basic affection, malnutrition, had not been affected: death was at most postponed for a short time. One expert is of the opinion that western medicine caused the population increase in tropical Africa ${ }^{97}$. This is a doctor's bias. The influence of the relatively few universitytrained doctors working in Africa is minimal, and even with more doctors and nutritionists neither the basic affliction, malnutrition, nor the resulting ill-health, can be cured with medicines. A drawback is, that Unicef's figures and indications cannot be statistically understructured, as no country in tropical Africa possesses a reliable system of (health) statistics ${ }^{98}$. But the impression prevails, that birth-rates are increasing, as are deathrates in children and that western intervention does not help.

94. 1596 was the first year covered by the earliest first-hand source found: *Ultzheimer, A.J. Warhaffte Beschreibung ettlicher Reisen in Europa, Africa, Asien und America 1596-1610. Neuausgabe Tübingen, 1971.

95. The state of the world's children 1989. New York: UNICEF, 1989, 1: while excluding child death-rates in countries such as Angola, Chad, Ethiopia and Mozambique.

96. UNICEF (1989) passim, 11

97. KING, M. (1990), passim, 664-667.

98. IMBERLAKE, L. Africa in crisis. London and Washington D.C.: International Institute for Environment and Development, 1985, 41. MCMASTER, D. Can Africa feed itself? Occasional papers no.9. Centre of African studies. Edinburgh University, n.d., 3. 
One may conclude that, as long as the former methods of birth-spacing and of the provision of sufficient weaning foods are not taken up again, there will be no end to malnutrition. Western contraceptive methods and industrial weaning foods are too expensive, even if the rural populations could be reached. The new governments of the African countries have not been able to redirect the course, despite all "development efforts", or for that very reason.

The (rural) Africans themselves have to solve the problem, and there are indications that this is possible. In several areas in tropical Africa communities are innovating, and specializing in, agricultural methods ${ }^{99}$, and in rural organization $^{\text {pon }}$, without Western "aid". If this will lead to a stable society and to a better position of the female farmer, a new tradition may begin. Perhaps a solution to malnutrition will arise from within.

99. e.g. COUTY. Ph.. L'agriculture africaine en réserve. Réflexions sur l'innovation et l'intensification agricoles en Afrique tropicale. Cahiers d'études africaines, 121-122, XXXI-1-2, 1991, 65-81.

100. PRADERVAND, PIERRE. Une Afrique en marche - La révolution silencieuse des paysans africains. Paris: Librairie PIon, 1989, BAMBANOTA, MOKONZI. Le travail en groupe: force du futur developpement des paysans de la zone de Wamba au Zaire. Bulletin of the International Committee on urgent anthropological and ethnological research. Nos 30-31, 1988-1989, 117-126.

The bibliography of European doctors who travelled in tropical Africa before 1880 can be obtained from the author. 